\title{
The Riddle of the Fowl and the Eagle
}

\author{
Alvin Yapan, translated by Christian Benitez
}

Department of Filipino, Ateneo de Manila University, The Philippines

\begin{abstract}
Alvin Yapan's "The Riddle of the Fowl and the Eagle" (Filipino: "Ang Bugtong ng Manok at Agila") ${ }^{1}$ teases at the boundaries between the cultural, the natural, and the supernatural, in order to foreground a contemporary Philippine conundrum that elucidates an ethical concern. The story questions what it is to be human, and what it means to be so in times that are rather inhumane. In the context of this text, this is simultaneously a concern with the meaning and value of animality. Through its rhythm, the text demonstrates a contemporary tropical consciousness that simultaneously navigates the individual and the collective so as to confront ecocritical anxieties and creating a story of the ecogothic. ${ }^{2}$ The translation of this text therefore opens this local tropical story to current discourses involved in analyzing global ecocritical predicaments.
\end{abstract}

Keywords: ecogothic, tropical, Philippines, culture, nature

\footnotetext{
1 "Ang Bugtong ng Manok at Agila" won the first prize for the Filipino Short Story in the $64^{\text {th }}$ Don Carlos Palanca Memorial Awards for Literature, 2014. The story was first published in Alvin Yapan's collection Sangkatauhan Sangkahayupan (2016, pp.196-217) by Ateneo de Manila University Press.

${ }^{2}$ Principe (2014) defines ecogothic as texts that examine "the construction of the Gothic body unhuman, nonhuman, transhuman, posthuman, or hybrid - through a more inclusive lens, asking how it can be more meaningfully understood as a site of articulation for environmental and species identity" (p.1).
} 


\section{The Riddle of the Fowl and the Eagle}

$\mathrm{H}$ e slaughtered the animal as if it were a fowl. First he carefully plucked the feathers from the base of its skull. Then he cut its throat with the dagger he would usually use to part the green of the forest, this time letting the red blood drip. He hung the animal upside down until the blood drained out. He collected each drop into basins with rice grains so it wouldn't dry too quickly. He grilled it, especially around its wings, supple as they were when he plucked its feathers. Didn't he know, they asked, that the eagle he shot had a name. The animal he killed had a name.

Banaag. The name came from the Imperials, the family who owned the only gasoline station at the center of their town. That is, if it was considered a town center at all, that asphalt road at the foot of the mountain, connecting the houses to business establishments visited occasionally by residents of the small barrios claimed by the forest. The name, they said, alluded to the glimmer of a new relationship between man and nature. ${ }^{3}$ The time was coming when nature would no longer be mistreated. According to the Bible, the drivers read from pamphlets handed to them each time they gassed up, humans need to embrace their responsibilities as stewards of plants and animals.

Banaag was the third eagle to be set free in the forest after being raised for several months at the Eagle Conservation Center. The Imperials were among the most devoted supporters of the Center. They also sponsored the largest tree-planting campaign for the area's diminishing forest. The family had already planted over a thousand trees, enough to create a sanctuary for the eagle hatched, raised, and eventually set free by the Center — only to be shot down by him four months later.

When he was invited to the precinct he was seated by the Chief's table. Barangay patrols surrounded the Chief and the Captain who had personally invited him. Everybody wanted to nose in, for it was a peculiar invitation. Everyone was used to couples fighting after finding out about each other's infidelities. They were used to residents filing complaints against their neighbors for being too noisy, drinking and singing karaoke all night. This was a different fight they were about to witness, since it was between man and animal. Who would even file the complaint? The patrols asked. Previously if animals were ever involved in police reports, they said, they were only carabaos ${ }^{4}$ stolen by those from outside their town. So now they waited, wanting to see who would sign the thick police blotter.

\footnotetext{
${ }^{3}$ Banaag is defined in Diksiyunaryo-Tesauro Pilipino-Ingles (1972) as "distant glitter or radiance; soft ray; glimmer."

${ }^{4}$ Carabao (Filipino: kalabaw) is a domestic swamp water buffalo indigenous to the Philippines.
} 
He had calmly obliged the invitation to visit the police precinct. He would only be asked a few questions, they said. So he told his wife and son to just meet him there. In front of everyone who gathered there, he was interrogated about the GPS the people from the Center found buried in his backyard. It wasn't clear to him what a GPS was. Among those who arrived at the precinct was Mrs Ynez Imperial. She was the one who reminded the police to never put him in cuffs. They didn't want to highlight the shame the ceremony of setting the eagle free - attended by even the Mayor and the Congressman - had led to. The woman brought along her small Shih Tzu, dressed in a blue sweater in case it got cold. The morning was still foggy when they set out for the precinct. The Shih Tzu was named Lucky. Everybody knew Lucky, who would cry like a human, calling for the Mrs, whenever it would wake up in the morning without her by its side.

He was looking at Lucky when he was asked if he knew of R.A. 9147. The Shih Tzu was also looking at him, as if expecting an answer. It was impossible that he didn't know. The republic act was posted on almost every wall of the precinct. Everybody just wanted to know if he could read. He, on the other hand, wanted to know why the dog, dressed as it was, wasn't wearing a pair of trousers. He knew about the republic act. Their entire barrio has been even gathered to talk about it. It was prohibited to kill an eagle in the forest surrounding their barrio. Six to twelve years imprisonment would be the penalty.

But it wasn't an eagle he killed-it was merely a big fowl, he defended himself. The Center didn't find any eagle bone in his backyard. No bone, no nail, no skull. Only that thing which they called a GPS was somehow found there. Regardless of a Republic Act, he was certain that it wasn't an eagle he shot. For what he and his family ate tasted like a fowl. They were more familiar with the flavors of vegetable and freshwater fish, but they couldn't mistake the flavor of a fowl.

It really tasted like a fowl? The patrols, the police, and the Barangay Captain asked. They were all questioning if it actually did taste like a fowl, just as they were told, since none of them had ever tasted an eagle in their whole lives. An eagle's life was worth a hundred thousand to a million pesos, if they would ever want to taste it. How expensive, exclaimed one of the patrols, he would feel cheated if it were really to taste like a mere fowl.

Lucky barked. Everyone turned to the Shih Tzu. Mrs Imperial touched the dog's head instinctively. It reminded him of how his wife would touch their son's hair. He didn't expect an animal with such soft fur could make such a shrill sound. Mrs Imperial's dog, they said, didn't like where the conversation was going. Taste shouldn't be the basis 
of their relationship to animals. The patrols, the police, and the Barangay Captain looked at each other, as did everyone who came to the precinct, including his wife and son.

It was just as well his wife and son arrived then. Everyone in the precinct was beginning to gang up on him. But what they ate did taste like a fowl, his wife and son insisted. They hoped that their testimonies could save him so they could all go home soon. What they believed to be merely an invitation for an enquiry had already stretched to noon. Good thing his wife and son had packed food; he couldn't even go pee without being accompanied.

His family knew what a fowl tasted like, and the Imperials had something to do with their confidence. The only bird he could remember shooting in the forest tasted like the fowls they had raised. Five chicks had been given to them by the Imperials, so they could breed them in their backyard and wouldn't need to depend solely on the forest for their survival. Once they passed by the Imperials' house downtown while selling wood collected from the forest. The Imperials collected orchids, as well as dogs that all barked. It was then that he first saw Lucky. The rumors in their barrio were true, Mrs Imperial even paid for a helper to play with the dog. He thought at first that it was only a ball of fiber drifting on a patch of grass. But it turned out to be a dog. Good thing the helper that the Mrs hired wasn't asthmatic, he thought as the Mrs bought their wood. After being reprimanded by the Imperials to never cut tree ferns again, the family gave them the five chicks. They said they were giving them chicks instead of grown fowls so they would learn to work hard for what they ate, and not to simply take. They even lectured them on the difference between giving a fish and teaching people how to fish - people like them who needed to make a living.

"Clip their wings when they grow, so they won't run off and roam," Mrs Imperial instructed before they left, and her dogs of various shapes, sizes, and colors barked.

He could still remember their way back to their barrio up in the forest, how light the chicks weighed inside the woven bag poked with holes. The heaviness of the tree ferns they had carried were now replaced with the lightness of these chicks. The blackness of the trees, were now the whiteness of these animals. It was whiteness so pure, only to be replaced eventually with blends of red, brown, and black of grown fowls, no matter the whiteness of the grains they fed them.

Soon they slaughtered three of the five fowls. They couldn't wait for the fowls to lay eggs first before tasting their flesh. They just kept a hen and a rooster to breed, in case the Imperials would drop by their barrio and check on them. The Imperials would drop by from time to time to add more trees to the number they had planted in the forest. It 
became their ritual whenever a driver would complain about them mixing water into the gasoline they sold, making their jeepneys belch even blacker smoke by the time they got to the Land Transportation Office. He owed it to the Imperials for having learned the taste of the animals he raised. Despite the taste of vegetables and freshwater fish to which they were more familiar, he couldn't easily forget the taste of a fowl.

But it might have only tasted like a fowl since the eagle in question was also raised. It didn't really grow in the forest, they were reminded by a patrol who owed as much to the Imperials. So despite it tasting like a fowl, it could still be an eagle that he had shot-an eagle that was only freed eventually after being raised in captivity. But what does captivity even taste like? The taste of the husk of grain, mashed in water and turned into feed? A taste as familiar as the scent of the sun sticking to their skin after an entire day of farming. So it isn't the meat of an animal as elusive as a wild boar or a monitor lizard. But who can even know the taste of an elusive meat when they had all been born under the law forbidding its consumption? Who could tell them about the taste of elusive meat? He turned to Lucky again and wondered if Mrs Imperial's dog had ever eaten a lizard. For if so, the Shih Tzu could help answer whether it was an eagle or a fowl he had shot.

Before Lucky could respond, the people from the Center chimed in. Whether it tasted like a fowl or not, they asked if he had even noticed the GPS tracking device attached to the animal's foot. They were making the conversation about it again. There was a metal ring attached to the right foot of the eagle. Didn't he wonder? By then, Mrs Imperial had let the Shih Tzu onto the floor. The dog was bored; it was now roaming around the precinct. Mrs Imperial's husband and their daughter had also arrived. Lucky's caretaker, who wasn't asthmatic, was busy chasing after the Shih Tzu. The Mrs was already taking too long in the precinct. But he didn't really know anything about the GPS, he replied. He thought that the metal gleaming in the dark forest before he pointed his gun and pulled the trigger was the metal spur of his runaway fowl.

The people from the Center were worried that the evidence they found in his backyard would end up being disregarded. How would what he mistook to be a fowl in the middle of the forest even have a spur? They asked. Because it was a fowl that ran away, he insisted. Lucky barked as if mimicking his every word. The rooster escaped because they didn't clip its wings, as the Imperials had advised. A fowl to whose feet he had tied a spur. He was already training it for a cockfight since it had mated with the hen. So when he saw it in the middle of the forest, he shot it right away so it wouldn't run away anymore, so he could make use of it. That wasn't a metal spur, the people from the Center told him, because it has the electronic device used to locate the eagle to whose feet it was bound. 
There is such a thing? Asked the surrounding patrols. Something you just attach, and you will be found! Like the aswang, whispered those who were from the barrio. ${ }^{5}$ Because the aswang could detect each conversation that mentions it, no matter how private. Maybe it really was an aswang, the patrols agreed. They likewise could not believe what the people from the Center were saying. Perhaps they were tricking them all so he would confess sooner, so the police could resolve the case, and Lucky would finally hush his shrill barks, which were already annoying them to the point of wanting to kick the dog. And so he would be imprisoned straight away for six to twelve years, since he didn't have a million pesos to pay the fine.

His fellow townsmen believed that it was really an aswang he shot. They were certain it was neither fowl nor eagle, because they knew the fate of his runaway rooster. Even when he asked them if they had seen his valued rooster, they didn't answer. He didn't find his fowl in his neighbor's stoves and on their plates. It wasn't behind their woven walls poked with holes. Because they'd already soothed their guts with his fowl, so they wouldn't be poked by hunger. They told him that the rooster he was looking for probably ran off to the forest. He simply believed his townsmen because it was also his fault. He didn't listen to the advise of the Imperials: to clip the fowl's wings so it wouldn't roam around.

They didn't clip the fowl's wings because the mere idea of it made them laugh. They couldn't fully grasp the image of a fowl resting above in a tree with its wings clipped. How would the poor fowl even reach the top of a tree? Would it mimic the cat? If the fowl wouldn't be resting above in the trees, it meant that it would be resting on the ground like a rat. It might just get eaten by the rats. It was truly funny, thinking of a fowl like a cripple trying to rest but couldn't. Just thinking about it, they couldn't stop laughing. They didn't do it because they were afraid that if they did clip the fowls' wings, they might never stop laughing. They might not be able to work anymore. How could they even hunt while laughing? And when they went fishing, they might not catch anything at all. They might even insult a diwata and nuno in its punso when roaming around the forest, and would end up being punished. ${ }^{6}$ The trees might not bear fruit anymore.

\footnotetext{
${ }^{5}$ An aswang is commonly described as "a combination of vampire and witch almost always female. They are sometimes used as a generic term applied to all types of witches, manananggals [i.e., aswangs who can split their bodies in half, with the upper torso able to fly with its pair of wings], shapeshifters, lycanthropes and monster." (Miller, McBrewster, \& Vandome, 2009, p.45).

${ }^{6}$ The diwata is "a mythological figure similar to fairies or nymphs. They are said to reside in large trees, such as acacia and balete and are the guardian spirits of nature, bringing blessings or curses upon those who bring benefit or harm to the forests and mountains." (Miller, McBrewster, \& Vandome, 2009, p.51). The nuno, on the other hand, is "a dwarf-like creature... believed to live in an anthill or termite mound, hence its name. Literally, nuno sa punso means Ancestor/Grandparent of the anthill." (Miller, McBrewster, \& Vandome, 2009, p.62).
} 
When the word started spreading in their barrio about sightings of something with enormous wings flying around the forest, he immediately thought of his rooster that had ran away. He wasn't afraid that it was an aswang he might have seen in the forest-unlike his fellow townsmen who were immediately afraid because they knew it wasn't his runaway rooster. If what he shot was indeed an aswang, then what the people from the Center said was true: it could really be traced back to him. For that is how sharp the aswang's sense of smell and instinct are. Despite the evidence having been buried already, it still got traced back to him. It really was the work of the aswang, the patrols and the townsmen agreed with each other. It was probably even done in participation with the chief of police, who knew who each of them had voted for last election, despite having voted in secrecy.

Without letting the others know about the evidence they had pieced together in their minds, the townsmen left one by one, afraid that it might really be an aswang he shot. They excused themselves one after another. It was getting dark, they needed to go. They still had to cook for their children left alone in their homes. Their carabaos needed to be led back to their shelters. In their minds, they couldn't shake off the fear that he ate the animal he had killed. If it wasn't really an animal - since they were the ones who actually ate the animal he mistook for what he had shot - it meant that the meat he ate was that of a human. Meat of an aswang. Meat of a human who could turn into an aswang. They pitied his wife and son. They muttered their conclusion to his wife and son during his interrogation. Both wife and son felt afraid. They immediately took back their testimony. They didn't really taste the meat of what he had shot so they couldn't be sure if it was an eagle or a fowl. The Imperials and the people from the Center were surprised by the change to their testimonies. But they didn't interfere anymore to hasten his verdict. No one else was called to testify to his story.

There was fear in his wife's eyes when she bade farewell. He thought it was fear for him because it seemed like he was certainly going to be imprisoned. But it was, in truth, an unnamed fear - for he was already a cannibal in her eyes. He couldn't go home with his family, the Chief said. He had to sleep in the precinct. So the invitation for interrogation became an invitation for a sleepover. His wife was relieved. Even his fellow townsmen were relieved. They could sleep through the night relieved from the fear of someone devouring them.

Even the Imperials and the people from the Center were relieved. If it was really an eagle he had shot, whether it tasted like a fowl or not, he should still be imprisoned because according to them animals have rights. Although animals couldn't sign the blotter, they could still file a complaint on their behalf. The patrols were dumbfounded by the Imperials. Although the Imperials had already answered the question bothering 
the patrols; they just couldn't believe that the Imperials saw themselves as animals. Whether it tasted like a fowl or not, Mrs Imperial's husband clarified, he did confess that he had shot something, and something died because of him. Let the piskal'give his verdict tomorrow as to whether it was an eagle or a fowl he had shot. For now, they had to go home so their pet Shih Tzu could rest. When the Imperials finally left, Lucky turned to him as if to bid him goodbye.

Like the steel cell bars, the questions he had to answer before the piskal the following day were hard and solid. He didn't know why the Imperials couldn't understand his answer: that he was sure it was a fowl he ate, and not an eagle. It was the same answer he would give the piskal the next day. He was turning it around in his head: why couldn't they possibly believe he knew what a fowl tasted like? It was as if they couldn't hear him, as if only Lucky could hear him. Because every time he spoke, the Shih Tzu would bark immediately. To his every word, the dog would return a bark. He thought that the dog probably really understood him. But it was impossible that he could be understood by a dog and not by humans.

When he was finally left alone in the prison cell, he heard himself. But what came out of his mouth weren't words anymore, but chirps. That must be why the Shih Tzu barked each time he spoke. It really was impossible then for the dog to understand what he said, instead it probably thought he was a bird to be played with and eaten. That was what he expected the dog would do if it saw a house lizard on the ceiling. The same puzzle that had been bothering him came back: he still didn't know if he was chirping now as a fowl or an eagle. But this was followed by another mystery his townsmen already confronted: birds weren't the only ones to chirp, the aswang also does. Now he understood the fear he had seen in his wife's eyes. It was then that his own eyes were opened. Even he felt afraid of himself. He might become an aswang at any time now because it was the meat of an aswang that he had eaten. It was probably the beginning of his transformation: the loss of his voice, and his chirping. He had to be sure.

He first tried finding where the chirping came from in his body. Did it come from his throat or his stomach? Word has it that the chick of the aswang would chirp from the stomach. It was where it would hatch, that black fowl egg which was only to be found in the forest, after being incubated by anyone who wanted to become an aswang. He tried to chirp again; but still he couldn't be sure if the sound came from his throat, when it also reverberated up from his very stomach.

\footnotetext{
${ }^{7}$ Piskal can be translated as the term fiscal in the limited sense of a magistrate in a small precinct court.
} 
He thought of another answer to his puzzle. If he were really an aswang, he shouldn't have been caught so easily. They should have had a harder time catching him. He should have first been thrown a handful of rice grains blessed with holy water, after being caught waiting beneath elevated huts. He would be busy picking up the grains of rice, one by one, until caught by the sunrise, making him lose his power. But it wasn't the case; he was indeed caught easily. He was only invited, and he immediately obliged. Maybe he really was a bird. It was impossible that his chirping came from his stomach. He might have only become a bird from eating the runaway fowl from the forest, since he forgot to clip the wings of the chicks given by the Imperials. He went back to his earlier assumption that he was a bird because none of his townsmen confessed to eating his runaway fowl. It was only then that he was able to lie down, relieved of his momentary panic.

Then he suddenly felt the interior of the prison cell become smaller. His arms grew longer. His fingers and toes grew longer. He grew scales on his arms and legs. His nails grew longer and sharper. His skin thickened like rubber. His genitals shrunk back into his groin. Even his nose shrunk from his face and back onto his skull. Only two narrow holes remained. His teeth fell off like rice grains, scattering on the floor. His mouth protruded and his lips sharpened into a beak. His hair fell off, his wings sprung out. The prison cell became too small for an enormous bird. His shoulders and arms were cramped. He didn't know if he should fold his wings, because if he did they would be touching the ground. But if he were to spread his wings, their joints would hit the light bulb. He might just get electrocuted.

He was still deciding what to do with his wings when he felt the dogs coming. He only felt them, because their steps outside his prison cell were quiet. Although now a bird, he was still dumbfounded by what he saw. An askal was walking on two feet as if it was a human. ${ }^{8}$ It might not have been wearing footwear, but the dog was wearing camisa de chino and walking with a cane. It was also wearing glasses. It was with Lucky the Shih Tzu, and another dog even smaller than the Imperial's.

He was even more dumbfounded when the askal spoke. It introduced itself to him. Its name was Dante, it said, and their third companion was Pomeranian. The introductions were made before he even asked. Why did it wear a shirt but not trousers? They could walk like humans and speak, but they still couldn't wear trousers.

\footnotetext{
${ }^{8}$ Askal is a colloquial term for street dog, abbreviated from asong kalye. Philippine animal advocates generally disprove of its usage, as the term "can be derogatory and suggests mangy, disease-ridden creatures that roam the city streets, subsisting on garbage scraps" (Kalaw, 2007). As a response to this, aspin is preferred, abbreviated from asong Pinoy, which translates as "Filipino dog," emphasizing the dogs' being a native breed. In the present translation, however, the original word choice is retained, so as to emphasize the desired connotation from the source text.
} 
Since the dog had already introduced itself, he felt inhibited questioning the extent of its rights as an animal when it came to clothing. He felt shy, lest the dog be insulted. After all, who was he to complain about dog clothes? It was he who was a bird inside a cage. He didn't have the right to complain that the dog talking to him wasn't wearing trousers.

"You know what your problem is?" Dante asked.

He was about to say his cramped wings. But since the experience of having wings was still new to him, he wasn't able to articulate it to the dogs right away. It took him a while to respond.

"You don't know how to dress up."

"Don't you realize you are naked," Lucky added. "You're such an embarrassment for an animal."

He looked down. He was expecting to see his genitals, ready as he was to cover them with his wings. But there were only feathers. When he was still a human, he never viewed animals as being naked. But now, it was an animal who was telling him - now an animal himself - that he was actually naked. The three dogs murmured to each other, the askal bowing down to whisper in the Shih Tzu's ear, who then bowed down to whisper in the Pomeranian's ear.

He caught what Pompom the Pomeranian said: "He's an animal. He just doesn't know it."

"And maybe that's why the humans didn't recognize you as an animal," continued Dante.

"Because you weren't wearing anything," finished Lucky.

"What should I do?" He cautiously asked the three dogs who walked like humans. Dante, whom he observed to be the leader, spoke for all three.

"Don't be angry with our owner. She's a good person. She's the one who opened our minds to our rights as animals-"

"-to our rights as animals," clarified Pompom, giving its two companions a meaningful look, reminding them to pity his situation inside the prison. 
"You're part of what our owner fights for. You're part of what her daughter stripped naked for in front of many people just so we'd be clothed. If she only knew you were an animal, she might've helped you."

"If you only had clothes," Lucky repeated.

"You just put our owner in danger. People might point out some gaps in what she fights for. Whether what she's throwing into jail is a man or an animal. People might say she disobeys the animal rights she herself proposed. We owe her much."

"You need to escape from here because she might get into trouble tomorrow in the court." The Pomeranian couldn't control itself anymore.

$\mathrm{He}$, on the other hand, couldn't believe that animals were the ones to actually help him escape. But he shouldn't have been surprised, since he himself was now an animal. Lucky's thick fur was able to hide a key without anyone noticing. The dogs made him wait inside the prison cell for a little while. The askal went before Lucky and Pompom. The dogs weren't supposed to be seen in the precinct, since they had just escaped from their owners. Their owners would be surprised once they realized their dogs were nowhere to be found in their homes. He then suddenly heard Dante barking outside the precinct. It was barking at a tree. It didn't stop until the policemen guarding the precinct woke up. The policemen went out to see what the dog was barking at in the trees. There might be a kapre only dogs could see. ${ }^{9}$

It was the cue for him to move. Lucky and Pompom went out first, making sure no one else was guarding the precinct. Only then did he follow. When he reached the precinct doorway, Lucky and Pompom joined in barking at the treetops. Even the policemen were surprised by the barking of the dogs. He then slipped out of the precinct, unfolded his wings and took flight into the barely moonlit sky. The policemen only heard the flapping of wings. They felt more afraid when they didn't find him inside the prison cell anymore. What the townsmen whispered was probably right: before going home, the townspeople told them that it was an aswang they had imprisoned. By then, the policemen had already pieced everything together, including the change to the wife's and son's testimonies, even the barking of the dogs at the treetops. They all agreed that it was neither fowl nor eagle their prisoner had shot, but an aswang. It was meat of an aswang he had eaten, and as punishment, he himself had become an aswang.

\footnotetext{
${ }^{9}$ The kapre is "a Philippine mythical creature that could be characterized as a tree demon, but with more human characteristics. It is described as being a tall ( 7 to $9 \mathrm{ft}$ ), brown, hairy male with a beard. Kapres are normally described as smoking a big tobacco pipe, whose strong smell would attract human attention." (Miller, McBrewster, \& Vandome, 2009, p.53).
} 
They didn't bother chasing after him anymore, because becoming an aswang already sufficed as punishment.

So just when he was finally certain that he was a bird, the authorities became convinced that he was an aswang. With every beat of his wings, he became more certain that he couldn't take being mistaken for an aswang. He could take being called an animal, but never an aswang. He was not a cannibal. He wouldn't eat the meat of his fellow men, even in the un-human form of an aswang. His resentment to his wife slowly grew. She had forsaken him. She even swayed their son to do the same. He flew and flew. He flew away from their barrio, the barrio where he was born human and now left as an aswang. He had to fly away from there, to run off, to escape. He flew beyond the forest surrounding their neighborhood. Until he finally found a place he could rest.

How many mountains and lakes did he cross to reach the place of lights. From above, it wasn't the asphalt roads that connected houses and buildings, but the lights. He saw numerous people walking down the street. He also saw animals he could blend with so he'd disappear. He wanted to start anew. Even if it were a beginning as an animal, as long as he could begin again. He quickly tried finding clothes to wear, just as the dogs had advised him to do. What kind of clothes would suit him? A pair of trousers? A sweater? A shirt? He came to where the animals gather to find something to wear. He passed by an animal spa, where people were the ones to bathe them, using any shampoo they wanted. In the midst of dogs getting haircuts and being blow-dried, he decided that neither a shirt nor a pair of trousers would suit him. He wasn't a dog, but a bird. He needed to make his own identity as an animal. Maybe he didn't really need to wear clothes. Maybe it would be enough to have an accessory on his body to prove that he was really an animal and not an aswang. Maybe he could begin with a pair of glasses like the askal. Or maybe he could wear a woven hat. That wouldn't interfere with his flight. When he passed by rows of mirrors of a veterinary clinic, he decided that a pair of glasses atop his beak also wasn't for him. His eyesight wasn't impaired anyway. So, a woven hat for him then. He would look respectable in it.

But when he went to the pet clothing store to buy a hat, he wasn't let inside precisely because he wasn't wearing anything. At first, he thought it was because the people might have thought he didn't have any money. But when he returned after begging for alms outside the church and in the streets, he still wasn't let inside. So, he stayed outside the store for a while to see why he wasn't allowed to go in. He noticed it wasn't the animals who buy their clothes but the humans. He was still adjusting to the laws of the animals. He had to be clothed so he could enter a clothing store? But that was exactly why he wanted to enter the clothing store, to have clothes! While figuring out the conundrum of where animals' clothes came from, he went to a park where animals 
were walked by their humans. In the middle of their jogging, two huskies advised him that he should find an owner who would give him his first clothes. What he needed wasn't money, but a human. Only humans needed money. But how could he find himself a human? He asked the dogs. An old Dalmatian answered him: he first had to be captured by humans and caged in an animal pound, especially if he had no papers. He just had to roam by the road and wait for his impounding.

He panicked when he heard the advice of the old dog. He didn't want to be caged again, especially since he just escaped from his old life where he was mistaken for an aswang. He was still thinking like a human, the Dalmatian observed. He had to accept his being animal graciously. At first, he refused to believe the dogs he asked in the park: they could just say those things, he reasoned, because they were walked by their humans. But when he went to the streets, the stray animals gave him the same advice. Humans were indeed the denomination among the animals.

When he was caught and brought to the animal shelter, he was put into a cage with countless askals and pusakals. ${ }^{10}$ They were all hoping to be adopted by someone. They were visited in the cage by a veterinarian. It was there that he experienced eating on a plate again. It was there that he felt embarrassed to just defecate anywhere. It was there that his nose learned to distinguish again between foul and fragrant smells. It was there that he felt what it was like to bathe not just in rainwater. To each pouring of water to his body, his scales decomposed like rubber. He didn't notice that even his feathers and wings were falling off as if he was being poured with hot water. His beak softened again, and his nails receded. He had his lips and fingers again. Then the veterinarians were shocked by him: his captors couldn't believe it - a human had strayed into their cage! What an embarrassment, not having distinguished the human from the animal!

So just when he had decided to be a bird, he was recognized to be human, in the place where he had run off to so he wouldn't be recognized as an aswang. He was given clothes, but they were now clothes for a man and not for a bird. After being clothed, he was transferred to the Department of Social Welfare and Development of the town he went to as a bird, and now, unless he decided to run away again, seemed to be leaving soon as a human. He was seated again before a table in the head's office. But he didn't resist, and simply waited for someone to interrogate him again about the difference between the taste of a fowl and an eagle.

\footnotetext{
${ }^{10}$ Pusakal is a colloquial term for street cats, abbreviated from pusang kalye. Like the shift in terms from askal to aspin, Filipino animal advocates have recently suggested the shift from pusakal to puspin (Buelva, 2016).
} 
He first saw the Shih Tzu. He thought it was Lucky. But it was followed by another person. He thought that Mrs Imperial must have only hired a different helper. Maybe the previous one had developed asthma, he thought. But it was a different woman who came out and followed the caretaker of the Shih Tzu that greeted him. She introduced herself as Mrs Miranda. He shouldn't be worried, she said. The Mrs would look after him until he got better again. The Mrs would teach him a living so he could stand on his own feet. Mrs Miranda brought him to her vast hacienda, where many trees were planted. He wondered what the Mrs could possibly give him; as it turned out, chicks. Five fowl hatchlings. She said he could breed the fowls so he wouldn't have to depend on others. He was just told to never forget to clip the fowls' wings so that when the birds grow, they wouldn't run off and roam. 
eTropic 18.2 (2019) 'Tropical Gothic: Literary and Creative Works' Special Issue | 57

\section{Acknowledgment}

This translation is part of a project funded through the Loyola Schools Scholarly Work Faculty Grant 2019. The translator expresses his utmost thanks for this opportunity that allowed this work to eventuate in its present form.

\section{References}

Buelva, A. J. (2016, Jan. 5). Purina's "Puspins of Meownila" hightlights the good in local cats. MetroPets. Retrieved from https://www.metro-pets.com/news--features/category/puspin

Diksiyunaryo-Tesauro Pilipino-Ingles. (1972). Quezon City, Philippines: Manlapaz Publishing, Co.

Kalaw, A. G. (2007, Aug. 18). 'Askal' is out, 'aspin' is in. The Philippine Star. Retrieved from https://www.philstar.com/lifestyle/modern-living/2007/08/18/13642/lifestyle\#wtSY5opkk et3Lpgh.99.

Miller, F.P., McBrewster, J., \& Vandome, A.F. (Eds.) (2009). Philippine Mythology. Riga: Alphascript Publishing.

del Principe, D. (2014). Introduction: The EcoGothic in the Long Nineteenth Century, Gothic Studies 16(1), 1-8.

Yapan, A. B. (2016). Sangkatauhan at Sangkahayupan. Quezon City, Philippines: Ateneo de Manila University Press. 